\title{
Impact of Training and Mentoring Activities Which are Given to The Level of Interest And Capability Industrial Target Group In Adopting SNI ISO 50001
}

\author{
Dwi Apriyanti ${ }^{1,2}$, Aris Ika Nugrahanto ${ }^{1}$, Sanjaya Shrestha $^{1}$ \\ ${ }^{1}$ Industrial Energy Efficiency Project, United Nations Industrial Development Organization (UNIDO), Indonesia \\ ${ }^{2}$ Master Program of Energy, School of Post Graduate Studies, Diponegoro University, Semarang - Indonesia
}

\begin{abstract}
Energy consumption in the industrial sector in Indonesia is increasing as a result of population and economic growth. The government is aware of this and seeks the answer to improve industrial competitiveness and increase energy security through energy efficiency programs. Some industries have implemented energy efficiency programs as ad-hoc, but have not applied systematically, so the results are not optimal. Through the cooperation of the Ministry of Energy and Mineral Resources (ESDM) with the United Nations Industrial Development Organization (UNIDO), there has been training and mentoring activities for industry on Energy Management System (EnMS) based on SNI ISO 50001. Based on the results of identification through survey conducted to 226 industry that has attended the training and 64 industries that have been trained and received assistance, obtained data that $45 \%$ of industries have fully adopted EnMS SNI ISO 50001, $17 \%$ industry has adopted a part of EnMS SNI ISO 50001 and 38\% industry does not adopt EnMS SNI ISO 50001 altogether.
\end{abstract}

\section{Introduction}

Industrial growth contributes very important to economic growth in Indonesia. The industry's average energy demand grew by more than $2.7 \%$ per year from 2011 to 2035. This is driven by the shift of industrial-type growth from labor-intensive activities to energyintensive industries [1]. However, on the other hand, the industry as the largest energy user is a significant greenhouse gas emitter. Increased greenhouse gas emissions from burning fossil fuels and rising world fuel prices are a serious threat to environmental sustainability and Indonesia's economic sustainability [2]. Beside, one of the cause of high energy consumption is inefficiency in energy use. Thus, the energy costs incurred by the industry become very high resulting in financial inefficiency and declining product competitiveness.

The Government of Indonesia is fully aware of the threat, so that various policy instruments and programs are implemented, including issuing Government Regulation (PP) no. 70 of 2009 on energy conservation. In this regulation, organizations that consume energy greater than 6000 TOE (Ton Oil Equivalent) are required to apply the Energy Management System (EnMS).

Energy management is an integrated activity to control energy consumption in order to achieve effective and efficient energy utilization to produce maximum output through technical action in a structured and economical way to minimize energy utilization including energy for production process and minimize consumption of raw materials and supporting materials. Energy Management is done by :

1. Appointed an energy manager

2. Developed energy conservation programs

3. Performed energy audits on a regular basis

4. Implemented recommendations of energy audit results

5. Reported the implementation of energy management every year to ministers, governors, or regents/ mayors in accordance with their authority [3]

An international standard on energy management systems was introduced in 2011 with the issuance of ISO 50001 which was adopted by the National Standardization Agency (BSN) to become SNI ISO 50001 in 2012. ISO 50001, Energy Management System, is a standard used to manage energy performance, including energy efficiency and consumption. The ISO 50001 concept uses a Management System model with Plan Do Check Action (PDCA) cycle approach for continuous improvement. Indonesia as an ISO member identically adopted the standard become SNI ISO 50001 [4]

This SNI has many benefits, there are to develop policies related to energy efficiency usage, set goals and targets in line with energy policy, data usage to make objective decisions about energy consumption, measure the results to identify areas of energy efficiency improvement, review the effectiveness of energy policy and result from energy efficiency improvement, and implement sustainable improvements in energy

\footnotetext{
${ }^{*}$ Corresponding author : aprigreen@,gmail.com
} 
management practices. Improved in energy performance helps companies maximize the use of energy sources and energy-related assets so as to reduce energy consumption and energy costs.

The United Nations Industrial Development Organization (UNIDO), one of the United Nations (UN) agency participated in the making of ISO 50001 and in cooperation with the Government of Indonesia, namely the Ministry of Energy and Mineral Resources (MEMR), the Ministry of Industry (MOI) and the National Standardization Agency (BSN) in socializing and supporting the implementation of SNI ISO 50001 Energy Management System through the cooperation program "Promoting Industrial Energy Efficiency through System Optimization and Energy Management Standard in Indonesia ". This cooperation program runs from 2012 to 2017 (UNIDO, Project Document of Promoting Industrial Energy Efficiency Through System Optimization and Energy Management Standard in Indonesia, 2011), [5].

In its implementation, UNIDO in cooperation with MEMR has conducted several trainings on Energy Management System and System Optimization for industry and advanced training to produce national experts in the field. These trainings which was run from 2012 to 2015, have been done only for 6 sectors industry, there are chemical, textile, food and beverages, pulp and paper, ceramics, and others. The training was held for 2 days, where the participants who are representatives of the industry would be shared on how to apply energy management system in their own industries, in accordance with the clauses contained in SNI ISO 50001. In addition, this project also provided Energy Management System and System Optimization assistance to industries by making it a pilot company [6]. There are 28 industries which were become pilot companies on Energy Management System and 36 industries which are become pilot companies on System Optimization. The pilot company was implemented an energy management system accompanied by national experts, during their expert training periode, and under international expert supervision. Some of the pilot companies have been certified of ISO 50001.

Identification is conducted to determine the impact of training and mentoring activities provided by MEMR with UNIDO on the level of interest and capability of industrial target group in adopting SNI ISO 50001.

\section{Methodology}

The identification is done by conducting surveys to industries that have attended the training organized by MEMR together with UNIDO in the period of 2012 to 2015. The industries are divided into 6 sectors: chemical, textile, food and beverages, pulp and paper, ceramics, and others.

The survey was conducted by sending questionnaires via e-mail and conducting interviews with industry representatives, either by telephone or directly meeting at the factory.
The score of the questions given is between 0 to 5 [7]. Score 0 means that the company does not implement EnMS. A score of 3 means that the company $50 \%$ executes or implements EnMS. While score 5 means that the company implement $100 \%$ steps of EnMS. The evidence is the documentation of the system and the improvement of sustainable energy performance in each industry.

\section{Result and Discussion}

The survey was conducted for 226 industries, excluding UNIDO's pilot company (28 industries for Energy Management System and 36 industries for System Optimization). From questionnaires sent via e-mail and communications made via e-mail and telephone or directly meeting with industry representatives at the factory, feedback was obtained from 108 industries.

The questionnaire submitted contains questions about EnMS implementation in each industry regarding awareness of the importance of energy savings, management commitments, tasks and responsibilities, Significant Energy Users (SEU), Energy Performance Indicators $($ EnPI $=$ Energy Performance Indicators), objectives and targets, action plans, and internal audits that have been implemented [8].

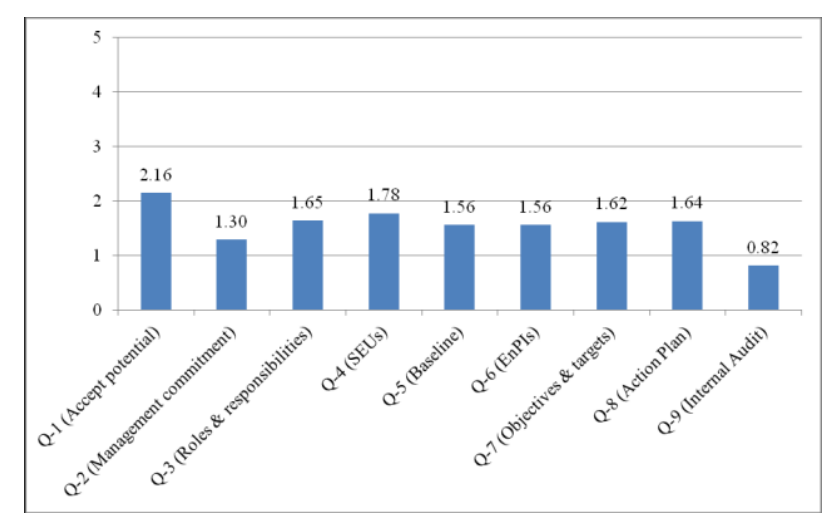

Fig.1. The score of all industries sector for each part of EnMS SNI ISO 50001

The expected result is the average score of each question reach 1.5. The results of each question based on the survey are shown in figure 1.

From the figure 1, the average is seen that for the question 1 (accept potential) obtained a score of 2.16 , it means that the industry are already aware that energy efficiency needs to be done. Question 2 (management commitment) obtained score 1.3 , meaning that only a few top management are committed to energy efficiency. Question 3 (roles \& responsibility) obtained score of 1.65 , meaning that industries which have implemented energy efficiency have made appointments to the energy team and their respective assignments. Question 4 (SEU's) obtained score of 1.78, meaning that the industries were already able to identify their significant energy users in their company. Question 5 (baseline) and question 6 (EnPIs) obtained score of 1.56 , meaning that 
industries have determined and have baseline and energy performance indicators to measure their energy efficiency level. Question 7 (objective and target) obtained score of 1.62, meaning that industry has determined objectives and targets related to energy efficiency. Question 8 (action Plan) obtained score of 1.64 , meaning that the industry has made the action plan in their energy efficiency implementation. Question 9 (internal audit) obtained score of 0.82 , meaning that there are still few industries conducting internal audits to evaluate overall energy efficiency implementation based on SNI ISO 50001.

Based on the results of each given question, it is recommended to conducted advanced training on how to identify and determine the baseline and EnPI (ISO 50006). In addition, advance training on internal audit systems for these industries is required. Related to commitment from top management, further research is needed to identify factors that can increase commitment from top management in EnMS SNI ISO 50001 implementation.

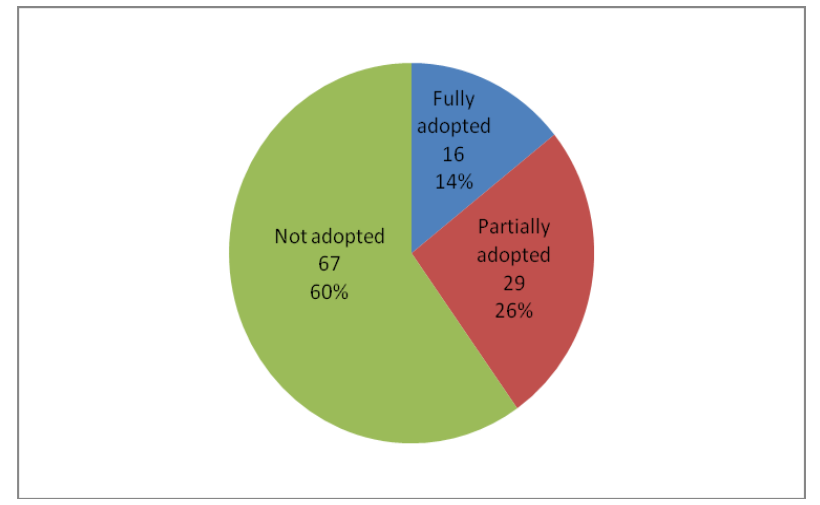

Fig.3. The survey result

Tabel 1. The number of adopted industries for EnMS

\begin{tabular}{|l|c|}
\hline \multicolumn{1}{|c|}{ Item } & $\begin{array}{c}\text { Number of } \\
\text { industries }\end{array}$ \\
\hline $\begin{array}{l}\text { UNIDO's pilot companies on Energy } \\
\text { Management System (fully adopted) }\end{array}$ & 28 \\
\hline $\begin{array}{l}\text { UNIDO's pilot companies on System } \\
\text { Optimization }\end{array}$ & 36 \\
\hline $\begin{array}{l}\text { Surveyed industries which was partially } \\
\text { adopted on EnMS }\end{array}$ & 29 \\
\hline $\begin{array}{l}\text { Surveyed industries which was fully } \\
\text { adopted on EnMS }\end{array}$ & 109 \\
\hline \multicolumn{1}{|c|}{ Total } & 109 \\
\hline
\end{tabular}

Based on the survey (excluding UNIDO's pilot company), it was found that the industries that have attended the training and implemented EnMS by fully adopting SNI ISO 50001 as many as 16 companies. The industry has implemented EnMS for 1 cycle of all stages to be implemented. Industries that partially adopt are 29 companies. That is, this industry has implemented EnMS but not yet completed 1 cycle, or just performing several stages only. While industries that do not adopt at all as many as 67 companies. That is, this industry does not implement EnMS, or has implemented energy savings but not systematically.

Taking into account the number of pilot companies that have attended training and obtained assistance, it can be obtained the number of industries that have implemented EnMS and adopted SNI ISO 50001 as many as 109 industry as shown in table 1 and figure 4 .

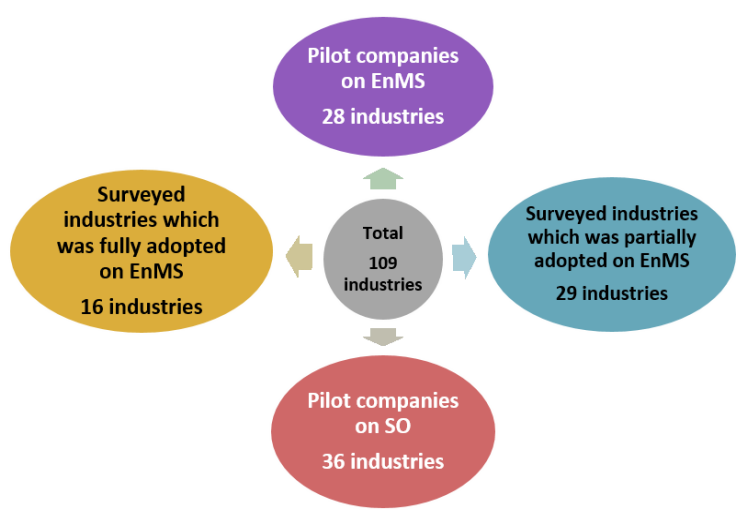

Fig.4. The number of adopted industries for EnMS

Based on the survey results and considered the pilot companies on EnMS and SO, it is found that $62 \%$ of industries has adopted SNI ISO 50001 compared to industry which was attended the Energy Management System and System Optimization training. However, some of the clauses of SNI ISO 50001 have not been fulfilled maximally.

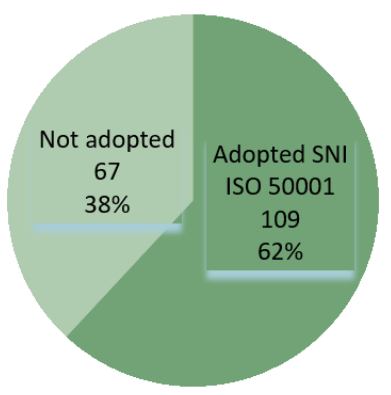

Fig.5. Adoption status

In order to have for more industries adopting SNI ISO 50001 and implementing sustainable development, it is necessary to conduct a more intensive approach between government and industry in EnMS implementation. By this effort, energy security can be achieved and negative impact of greenhouse gas emissions can be reduced.

\section{Conclusion}

Based on the identification result, the industries participating in the training and received mentoring of 
SNI ISO 50001 Energy Management System organized by MEMR and UNIDO, and have fully adopted the system are 80 companies. While still partially adopted are 29 companies, and who do not adopt at all are 67 companies.

Advanced training on ISO 50006 is required in determining the baseline and EnPI, as well as advanced training on the internal audit system. In addition, further research is needed to identify factors that can increase commitment from top management in implementing EnMS SNI ISO 50001

\section{References}

1. Wijaya, D. E., Tumiwa, F., \& Nugrahanto, A. I. (2017). In Buku Panduan Pelatihan Pembiayaan Proyek Efisiensi Energi bagi Lembaga Jasa Keuangan. Jakarta: UNIDO.

2. MEMR. (2016). Handbook of Energy and Economic Statistic of Indonesia. Jakarta: Ministry of Energy and Mineral Resources.
3. MEMR. (2012). Peraturan Menteri ESDM No. 14. Jakarta: MEMR (Ministry of Energy and Mineral Resources).

4. BSN. (2013). Konservasi Energi dengan Menerapkan SNI ISO 50001.

5. UNIDO. (2011). Project Document of Promoting Industrial Energy Efficiency Through System Optimization and Energy Management Standard in Indonesia. Jakarta: UNIDO.

6. Nugrahanto, A. I., Kamilya, N., Apriyanti, D., \& Hutasoit, N. (2017). Project Progress Report in Steering Committee Meeting. Jakarta: UNIDO.

7. UNIDO. (2013). Practical Guide for Implementing an Energy Management System. Vienna: UNIDO.

8. BSN. (2012). Sistem Manajemen EnergiPersyaratan dengan Pedoman Penggunaan, SNI ISO 50001. Jakarta: Badan Standardisasi Nasional.

9. ESDM, D. E. (2016). Statistik EBTKE 2016. Jakarta: Dirjen EBTKE Kementerian ESDM.

10. GEF-UNIDO. (2011). Project Council Document. GEF-UNIDO 